\title{
PERAN KOMUNIKASI ANTARPRIBADI DALAM KELUARGA UNTUK MENUMBUHKAN KARAKTER ANAK USIA DINI
}

\author{
Meni Handayani \\ e-mail: meni_handayani@yahoo.com \\ Pusat Penelitian Kebijakan Pendidikan dan Kebudayaan, Balitbang Kemendikbud \\ Jalan Jenderal Sudirman, Senayan
}

\begin{abstract}
Abstrak: Keterlibatan keluarga dalam mengembangkan kemampuan akademis dan perilaku sosial anak sangat dibutuhkan. Peran orangtua khususnya ibu pada anak usia di bawah 5 tahun sangat besar pengaruhnya. Orang tua harus tetap mengasuh dan mendidik anaknya agar dapat bersosialisasi dan berkomunikasi dengan baik. Komunikasi antarpribadi antara orangtua dan anak menjadi penting untuk membentuk karakter anak sesuai dengan pola orangtuanya. Karakter anak terbentuk dari keluarga, terutama dari bagaimana orangtua menyampaikan nilai-nilai moral, kejujuran, agama kepada anak melalui komunikasi yang baik. Orangtua tidak hanya menyampaikan melalui kata-kata, tetapi juga memberi teladan dalam tingkah laku. Strategi mencari informasi dari orangtua diperoleh dari pengamatan dan pengungkapan diri anak. Penting juga mendengarkan ungkapan perasaaan anak ke orangtua. Karakter yang terbentuk dari bawaan karena latar belakang budaya sang anak dibentuk dari keluarga dan masyarakat. Jadi, anak bisa berkembang sesuai dengan karakter akar budayanya. Pendidikan yang bersifat universal dapat dibuat seragam namun budaya adi luhur yang bersifat kearifan lokal sudah selayaknya untuk dipelihara, misalnya kebersamaan dalam keluarga, rasa malu bila melanggar norma yang berlaku, dan takut jika berbuat salah.
\end{abstract}

Kata-kata Kunci: komunikasi antarpribadi, pendidikan karakter, karakter anak usia dini.

\section{THE ROLE OF INTERPERSONAL COMMUNICATION IN FAMILY TO GROWING UP THE EARLY FHILDHOOD CHARACTERS}

\begin{abstract}
The involvement of family in developing academic competence and social behavior is badly needed. The role of parents particularly mother on the child of under 5 years old is very influential. The parents should keep parenting and educating their child to enable him/her socialize and communicate well. Interpersonal communication between the parents and the child is important to build the child's character suitable to the parents' style. The child's character is established from the family, particularly how the parents transfer moral value, honesty, and religion to the child through good communication. The parents do not do it just by words but by behavioral modelling. The strategy of seeking information from the parents is achieved by observation and expression of the child. It is important to listen to the child's expression. Inner character resulted from the child's cultural background is developed from the family and community. Thus, the child can develop based on the character of his/her cultural roots. Universal education can be conducted in uniform but the culture based on local wisdom should be maintained, such as togetherness in the family, being ashamed of breaking the existing values, and being afraid of doing the wrong things.
\end{abstract}

Keywords: interpersonal communication, character education, character of early aged child.

\section{PENDAHULUAN}

Keluarga merupakan tempat pertama dan utama bagi seorang anak untuk tumbuh, belajar dan berkembang. Anak pada usia dini bebas untuk mengeksplorasikan berbagai rasa ingin tahu yang ada dalam pikirannya, dengan bantuan dari lingkungan dan orang tua. Pada usia tersebut bentuk komunikasi mendapat peran yang sentral, artinya keluarga sangat diharapkan peran sertanya sebagai model untuk ditiru oleh anak.
Menurut resolusi Majelis Umum PBB (dalam Megawangi, 2003) fungsi utama keluarga adalah sebagai wahana untuk mendidik, mengasuh, dan menyosialisasikan anak, mengembangkan kemampuan seluruh anggotanya agar dapat menjalankan fungsinya di masyarakat dengan baik, serta memberikan kepuasan dan lingkungan sehat guna tercapainya keluarga sejahtera.

Komunikasi antarpribadi menurut Miller dan 
Steinberg (1975), berkembang dari prediksi hubungan komunikasi non-antarpribadi yang didasari pada data kultural dan data sosiologis kepada prediksi hubungan yang berdasarkan data psikologis. Dalam komunikasi antarpribadi partisipan melepaskan atribut-atribut pribadi dimana masing-masing mencoba berusaha untuk mengerti satu sama lain sebagai individu yang menyangkut keinginan, kebutuhan dan nilai pribadi masing-masing, sehingga hubungan dapat berkembang lebih akrab. Seorang anak yang masih berusia dini belum dapat mengungkapkan perasaannya dengan bahasa yang jelas ketika mereka ditinggal oleh Bapak mereka. Trauma yang anak rasakan lebih diungkapkan dengan bahasa tubuh, seperti sakit atau cengeng.

Peran ibu pada anak usia di bawah 5 tahun sangat besar pengaruhnya. Orang tua harus tetap mengasuh dan mendidik anaknya agar dapat bersosialisasi dan berkomunikasi dengan baik. Komunikasi antarpribadi antara orangtua dan anak menjadi penting untuk membentuk karakter anak sesuai dengan pola orangtuanya.

Carol Seefeld \& Nita Barbour (1986) mengelompokkan perkembangan anak usia dini dalam kategori: (a) bayi (infancy) lahir sampai 1 tahun, (b) toddler 1-3 tahun, (c) prasekolah 3 - 4 tahun, (d) kelas awal Sekolah Dasar $5-6$ tahu, dan (e) kelas lanjut Sekolah Dasar $7-8$ tahun. Tahap dari lahir sampai sebelum anak memasuki usia sekolah atau awal sekolah disebut anak usia dini.

Periode dari mulai akhir tahun pertama di dalam kehidupan anak sampai dengan anak berusia 5 tahun, kemajuan yang dicapai anak dalam perkembangan sosial dan kognitif cukup pesat (Monks, Knoers, Haditono 1994). Ini menunjukkan bahwa di usia 1- 5 tahun terjadi banyak pertumbuhan kemampuan anak. Anak usia prasekolah umumnya memiliki rasa ingin tahu yang besar, dengan mengajukan pertanyaan terus-menerus. Komunikasi antarpribadi yang dijalankan dalam suatu keluarga akan membentuk karakter anak usia dini sampai kelak dewasa.

Dalam tulisan ini mengupas bentuk komunikasi antarpribadi yang biasanya terjadi secara wajar namun tidak dirasakan oleh seseorang bahwa komunikasi tersebut akan membentuk karakter anaknya ketika dewasa. Untuk itu perlu dijabarkan agar dapat menjadi perhatian bagi keluarga dalam mendidik anak-anak dari usia dini.

Komunikasi antarpribadi merupakan salah satu bentuk komunikasi antar dua orang atau lebih.
Bentuk komunikasi ini biasa terjadi antarteman, kekasih, suami dan isteri atau orangtua dengan anaknya. Untuk lebih jelasnya perlu diketahui pengertian tentang komunikasi antarpribadi dan hal yang berkaitan dan pengertian keluarga serta anak usia dini.

Komunikasi antarpribadi menurut Joseph a Devito (2001) dalam karyanya The Interpersonal Communication Book, menginventarisir berbagai definisi komunikasi antarpribadi dari para ahli teori komunikasi dan secara alami mengklasifikasikannya dalam dua pembagian; definisi berdasarkan hubungan diadik dan pengembangan (development). Dilihat dari sisi hubungan diadik, komunikasi antarpribadi didefinisikan sebagai komunikasi yang berlangsung antar dua orang yang mempunyai hubungan yang mantap dan jelas, seperti layaknya hubungan anak dan ayah, pramuniaga dengan pelanggannya dan komunikasi yang berlangsung dalam suatu wawancara. Sementara itu jika dilihat dari sisi pengembangan suatu hubungan, komunikasi antarpribadi diartikan sebagai bentuk ideal terakhir dari perkembangan suatu hubungan komunikasi nonantarpribadi (Devito, 2001).

Kecerdasan interpersonal atau antarpribadi termasuk dalam kecerdasan jamak. Lazear (2000) menjelaskan bahwa kecerdasan interpersonal merupakan kemampuan yang digunakan untuk berkomunikasi secara verbal dan nonverbal serta kemampuan yang digunakan untuk melihat perbedaan "mood", temperamen, motivasi dan hasrat orang lain dengan diri sendiri.

Selanjutnya, dalam komunikasi antarpribadi terdapat reduksi ketidakpastian. Untuk mengetahui apa yang diinginkan dan dirasakan oleh anaknya, maka orang tua berusaha untuk mencari informasi. Usaha mencari informasi yang dilakukan orang tua untuk mereduksi ketidakpastian karena ketidaktahuan orangtua membuat dirinya menjadi bingung apa yang harus dilakukan.

Menurut Berger (1975) proses reduksi ketidakpastian ada dua. Pertama, proses eksplanasi sebagai atribusi yang retroaktif, yaitu proses yang menginterprestasikan arti tindakan-tindakan yang telah dilakukan dalam suatu hubungan tertentu dan menyiapkan informasi atas dasar interpretasi tersebut untuk dijadikan dasar bagi suatu interaksi di masa mendatang. Kedua, prediksi sebagai atribusi yang proaktif, yaitu memformulasikan atau mendefinisikan pilihan-pilihan perilaku dimana tersedia respon 
secara luas dan beragam bagi individu-individu yang berinteraksi, jadi mitra bicara sudah menyiapkan formula untuk mengantisipasi perilakunya.

Untuk mengurangi ketidakpastian hubungan antara orang tua dan anak biasanya orang tua bertanya langsung kepada sang anak untuk mencari informasi yang sebenarnya atau dengan pengungkapan diri (self disclosure) dari orang tua dan anak. Dalam komunikasi antarpribadi pengungkapan diri (self disclosure) digunakan sebagai salah satu cara untuk mendapatkan informasi dari orang lain agar kita dapat mempelajari bagaimana perasaan dan pikiran orang lain. Sekali seseorang terlibat self disclosure, berarti juga bahwa orang lain akan membuka informasi personalnya. Hal ini diketahui sebagai norma timbal balik.

Dalam hubungan antarpribadi yang berkembang, saling mengungkapkan diri cenderung bersifat timbal balik dan membuat suasana menjadi lebih akrab dari waktu ke waktu. Pengungkapan diri biasanya terjadi di antara dua orang (dyads). Pengungkapan diri terjadi dalam hal sebagai berikut. Pertama, Individu biasanya selektif memilih orang kepada siapa ia mengungkapkan sesuatu mengenai dirinya. Kedua, sahabat yang kita percaya, yang kecil kemungkinan untuk berkhianat. Biasanya laki-laki mengungkapkan dirinya kepada orang yang dia percaya. Perempuan mengungkapkan dirinya kepada orang yang dia merasa simpatik. Ketiga, dalam berinteraksi antara dua orang dalam pengungkapan diri biasanya bersifat simetris. Terjadi keseimbangan antara dua partisipan. Tidak mungkin yang satu bercerita tentang dirinya sedangkan yang lain menampung. Orang biasanya mau mengungkapkan sesuatu kalau dia merasa aman. Keempat, pengungkapan diri menjadi konteks hubungan sosial yang positif, jadi tidak mungkin terjadi pada hubungan sosial yang negatif dimana orang saling mencurigai (Jourard, 1959).

Self disclosure yang dilakukan secara tepat bisa menaikkan kesehatan fisik dan mental. Johnson, (1981: dalam Borchers: 2000 : dalam www. Mentalhelp. Net) menyatakan bahwa orang yang melakukan self disclosure lebih self content, lebih adaptif dan kompeten, lebih terbuka, lebih percaya dan mempunyai pandangan yang lebih positif terhadap orang lain daripada orang yang tidak melakukan self disclosure. Namun demikian self disclosure juga memiliki efek yang kurang baik terhadap seseorang.

Untuk menjalin suatu komunikasi antarpribadi yang efektif, self disclosure selayaknya juga dibarengi dengan menerapkan sikap mendengarkan karena dengan mendengarkan, kita memberikan perhatian, memahami, mengevaluasi suatu stimuli yang kita terima (O'Hair, Friedrich, Wieman dan Wieman, 1997).

Terdapat resiko dimana orang yang mendengarkan informasi mungkin tidak akan memberikan respon yang menyenangkan terhadap informasi tersebut (Borchers: 2000: dalam www. mentalhelp.net). Self disclosure tidak secara otomatis mengarah pada impresi yang menyenangkan.

Menurut pakar pendidikan, William Bennett (dalam Megawangi, 2003), keluarga merupakan tempat yang paling awal dan efektif untuk menjalankan fungsi departemen kesehatan, pendidikan dan kesejahteraan. Apabila keluarga gagal, untuk mengajarkan kejujuran, semangat, keinginan untuk menjadi yang terbaik, dan kemampuan-kemampuan dasar, maka akan sulit sekali bagi institusi-institusi lain untuk memperbaiki kegagalan-kegagalannya.

Pendidikan keluarga merupakan upaya pemerintah untuk memberdayakan keluarga agar memiliki akses, dan kontrol terhadap berbagai sumber daya termasuk sumber daya ekonomi dan partisipasi lebih besar dalam pembangunan karakter bangsa.

Terdapat beberapa penelitian yang mendukung bahwa keterlibatan keluarga atau orang tua dalam mengembangkan kemampuan akademis anak dan perlilaku sosial anak sangat dibutuhkan. Penelitianpenelitian itu juga memperlihatkan bahwa sekolah dengan metode yang efektif kebanyakan mulai menyadari pentingnya melibatkan orangtua dalam proses akademis di sekolah (Hornby, Garry, 2011).

Terdapat syarat-syarat mendasar bagi terbentuknya kepribadian yang baik. Menurut Megawangi (2003), ada tiga kebutuhan dasar anak yang harus dipenuhi yaitu maternal bonding, rasa aman dan stimulasi fisik dan mental.

Maternal bonding atau kelekatan psikologis dengan ibunya merupakan dasar penting dalam pembentukan karakter anak karena aspek ini berperan dalam pembentukan dasar kepercayaan kepada orang lain pada anak. Kelekatan ini membuat anak merasa diperhatikan dan menumbuhkan rasa aman sehingga menumbuhkan rasa percaya. Menurut Erikson, dasar kepercayaan yang ditumbuhkan melalui hubungan ibu-anak pada tahun-tahun pertama kehidupan anak akan memberi bekal bagi kesuksesan anak dalam kehidupan sosialnya ketika 
dia dewasa.

Kebutuhan akan rasa aman yaitu kebutuhan anak akan lingkungan yang stabil dan aman. Kebutuhan ini penting bagi pembentukan karakter anak karena lingkungan yang berubah-ubah akan membahayakan perkembangan emosi bayi. Kekacauan emosi anak yang terjadi karena tidak adanya rasa aman ini diduga oleh para ahli gizi berkaitan dengan masalah kesulitan makan pada anak. Tentu saja hal ini tidak kondusif bagi pertumbuhan anak yang optimal.

Kebutuhan akan stimulasi fisik dan mental juga merupakan aspek penting dalam pembentukan karakter anak. Tentu saja ini membutuhkan perhatian yang besar dari orang tua dan reaksi timbal balik antara ibu dan anaknya. Menurut pakar pendidikan anak, seorang ibu yang sangat perhatian (yang diukur dari seringnya ibu melihat mata anaknya, mengelus, menggendong, dan berbicara kepada anaknya) terhadap anaknya yang berusia di bawah enam bulan akan mempengaruhi sikap bayinya sehingga menjadi anak yang gembira, antusias mengekslorasi lingkungannya, dan menjadikannya anak yang kreatif.

Tugas utama pendidikan yaitu membangun karakter (character building) seorang anak, dan hal itu dimulai dari sebuah keluarga. Karakter merupakan standar-standar batin yang terimplementasi dalam berbagai bentuk kualitas diri. Karakter diri dilandasi nilai-nilai serta cara berpikir berdasarkan nilainilai tersebut dan terwujud di dalam perilaku. Bentuk-bentuk karakter yang dikembangkan telah dirumuskan secara berbeda.

Bangsa Indonesia memiliki budaya yang beraneka ragam. Masing-masing budaya memiliki nilai-nilai adi luhur. Transfer nilai-nilai adi luhur yang memiliki karakter baik kepada anak-anak terjadi dalam keluarga. Keragaman budaya merupakan aset bangsa Indonesia yang dapat diambil kearifan lokalnya yang nantinya akan membentuk karakter anak. Penyerapan nilai-nilai budaya yang terjadi mulai dari bayi yang ada di dalam kandungan sudah mulai merasakan perilaku ibunya. Bahkan persiapan mengajar anak untuk berkarakter sudah dilakukan ketika anak masih dalam kandungan. Pendidikan karakter anak tersebut yang dilakukan oleh orangtua dari berbagai macam budaya ini akan menjadi cikal bakal anak yang menghormati orang tua, bersikap santun, jujur, berbahasa halus dan berbudi perkerti yang baik. Modal dasar anak yang sudah berkarakter baik yang dididik dari keluarga baik dan sejahtera akan mempermudah dunia pendidikan mencetak anak-anak yang berkualitas.

\section{PEMBAHASAN}

Karakter bangsa yang kuat merupakan produk dari pendidikan karakter di tengah keluarga. Ketika mayoritas karakter bangsa kuat, positif dan tangguh bisa dipastikan keunggulan dan kemajuan sebuah bangsa merupakan buah yang dapat dirasakan oleh seluruh warga bangsa. Karakter anak terbentuk dari keluarga, terutama dari bagaimana orangtua menyampaikan nilai-nilai moral, kejujuran, agama kepada anak. Penyampaian nilai-nilai kebaikan dalam kehidupan tentunya dilakukan dengan cara komunikasi yang baik. Orangtua tidak hanya menyampaikan melalui kata-kata tetapi juga memberikan teladan dalam tingkah laku dan juga berusaha mendengarkan apa yang sebenarnya apa yang ada dalam diri anak.

Strategi Memperoleh Informasi dalam Usaha Mereduksi Ketidakpastian dalam Berkomunikasi

Strategi interaktif merupakan strategi yang baik digunakan orang tua dalam berkomunikasi dengan anaknya. Strategi ini melibatkan interaksi langsung antara orang yang mengamati dalam hal ini orang tua dan target dalam hal ini anak. Strategi ini tidak hanya dipakai pada interaksi awal saja tetapi juga pada tahap yang sudah akrab untuk membina hubungan yang harmonis.

Dalam kasus interaksi ibu dan anak-anaknya, umumnya menggunakan strategi pencarian informasi yang interaktif sifatnya. Pencari informasi merangkap pula sebagai pengamat partisipan (participant observer). Strategi ini tidak hanya dipakai pada interaksi awal saja tetapi juga pada tahap terjadi eskalasi hubungan yang akrab. Orang tua juga mencari informasi tentang anaknya untuk mendapatkan formula yang tepat mengatasi anaknya di masa datang. Menurut Berger (1975) proses interaktif reduksi ketidakpastian ada dua. Pertama, proses eksplanasi sebagai atribusi yang retroaktif, yaitu proses yang menginterprestasikan arti tindakan-tindakan yang telah dilakukan dalam suatu hubungan tertentu dan menyiapkan informasi atas dasar interpretasi tersebut untuk dijadikan dasar bagi suatu interaksi di masa mendatang. Kedua, prediksi sebagai atribusi yang proaktif, yaitu memformulasikan atau mendefinisikan pilihan-pilihan 
perilaku dimana tersedia respon secara luas dan beragam bagi individu-individu yang berinteraksi, jadi mitra bicara sudah menyiapkan formula untuk mengantisipasi perilakunya.

Orang tua terutama ibu mempunyai cara tersendiri dalam mencari informasi namun, secara umum para ibu mengamati perilaku anaknya sejak mereka lahir. Pencarian informasi oleh ibu dilakukan dengan strategi interaktif. Pencari informasi merangkap sebagai pengamat yang terlibat. Tindakan-tindakan yang dilakukan oleh anak-anak diinterpretasikan oleh ibu yang kemudian disiapkan sebagai bahan informasi. Pengalaman interaksi yang sudah dilakukan antara orang tua dan anaknya dapat dijadikan dasar menyiapkan formula untuk mengantisipasi perilaku. Jika anak mereka tidak mau makan, maka ibunya juga berusaha mencari informasi kepada anak mengapa tidak mau makan. Perilaku mencari informasi ibu terhadap anak merupakan usaha mereduksi ketidakpastian ibu agar dapat mencari solusi untuk mengatasi keadaan jika anaknya tidak mau makan.

Salah satu strategi yang digunakan dalam strategi interaktif untuk usaha pencarian informasi dari pihak lain adalah pengungkapan diri (self disclosure). Berkaitan dengan pencarian informasi, pengungkapan diri (self disclosure) adalah cara yang paling sering digunakan orang tua kepada anaknya atau sebaliknya. Self disclosure adalah cara untuk memperoleh informasi tentang orang lain, dengan begitu kita dapat mempelajari bagaimana perasaan dan pikiran orang lain. Sekali seseorang terlibat self disclosure, berarti juga bahwa orang lain akan membuka informasi personalnya. Hal ini diketahui sebagai norma timbal balik. Dalam hubungan antarpribadi yang berkembang, saling mengungkapkan diri cenderung bersifat timbal balik dan membuat suasana menjadi lebih akrab dari waktu ke waktu (Jourard:1959).

Orang tua memiliki strategi yang berbeda dalam memberi penjelasan terhadap anak-anak tentang apa yang terjadi dalam keluarga maupun tentang suatu keadaan dalam arti mengajarkan kejujuran. Pengungkapan tentang keadaan seperti pekerjaan bapak, pekerjaan ibunya, siapa kakek dan nenek, diungkapkan secara jelas kepada anak-anak dilakukan oleh ibu sebagai strategi agar anak-anak dapat mengerti keadaan yang sebenarnya. Informasi dari pengungkapan keadaan diri orang tua tentu diperlukan oleh anak-anak agar mereka tidak merasa ada hal yang disembunyikan dan akan menjadi masalah di kemudian hari. Ibu sebagai orang tua merupakan faktor penting dalam mendidik anak, karena perempuan mempunyai peran stratergis dalam menanamkan nilai-nilai moralitas yang membekali pertumbuhan karakter anak. Self disclosure yang dilakukan secara tepat bisa menaikkan kesehatan fisik dan mental. Johnson, (1981: dalam Borchers: 2000 : dalam www.mentalhelp.net) menyatakan bahwa orang yang melakukan self disclosure lebih self content, lebih adaptif dan kompeten, lebih terbuka, lebih percaya dan mempunyai pandangan yang lebih positif terhadap orang lain daripada orang yang tidak melakukan self disclosure.

Namun demikian self disclosure juga memiliki efek yang kurang baik terhadap seseorang. Anak usia dini yang masih berumur antara $2-5$ tahun, belum paham mengapa seseorang meninggal atau harus berpisah (cerai). Berdasarkan penelitian Meni Handayani, terdapat kasus pada dua orang anak usia dini kakak dan adik. Pada saat Bapaknya meninggal sang kakak berumur 5 tahun dan adiknya berumur 2 tahun. "Ayah kenapa ma? Ayah sudah gak ada "jawab mamanya..." mendengar hal tersebut anak menjadi bingung karena kenyataannya Bapaknya masih ada terbaring di hadapannya. Setelah Ibu menjelaskan kalau Bapaknya sudah meninggal dan tidak bisa bangun lagi, maka sang anak menjadi ketakutan. Reaksi anak terhadap keterbukaan Ibu adalah anak menjadi sakit panas beberapa hari (2005).

Jika kenyataan tentang kematian dalam hal ini kematian seorang Bapak tidak diberitahukan secara terbuka pada saat yang tepat maka anak juga akan merasa bingung mencari sosok Bapaknya yang biasanya selalu berada disisinya. Rasa kehilangan yang tidak jelas pada sang anak mengakibatkan anak selalu menunggu dan anak menjadi sering menangis tanpa sebab yang jelas. Oleh karena itu, self disclosure yang dilakukan secara tepat antara orangtua tunggal dan anak dapat memberikan ketenangan batin pada keduanya.

Untuk menjalin suatu komunikasi antarpribadi yang efektif antara orangtua dan anak maka self disclosure juga diikuti dengan menerapkan sikap mendengarkan karena mendengarkan dapat berarti memberikan perhatian, memahami, mengevaluasi suatu stimuli yang kita terima. Artinya dalam mendidik anak berkaitan dengan komunikasi, penting 
sekali mendengarkan perasaan, karena apa yang dirasakan oleh orang lain, jauh lebih bermakna dan mempengaruhi apa yang dilakukannya daripada yang dipikirkan. Di sini ada hubungan yang saling, anak mengungkapkan perasaannya dan orangtua mendengarkan, begitu pula sebaliknya. Pendidikan yang dapat diambil dari komunikasi antarpribadi ini adalah saling menghargai, jujur, terbuka tapi pada orang yang tepat dan dapat dipercaya. Hasil dari komunikasi tersebut adalah rasa bahagia, percaya diri dan menempatkan keluarga sebagai tempat mencari solusi dalam menyelesaikan masalah. Hal ini dapat menghindarkan anak dari pemecahan solusi yang tidak tepat dan salah bergaul yang arahnya kepada pemakaian obat terlarang dan pelarian ke arah negatif seperti nakal yang berlebihan untuk mencari perhatian.

Selain komunikasi verbal, juga terdapat komunikasi yang bersifat nonverbal seperti mengelus dan memeluk. Kebutuhan akan stimulasi fisik dan mental juga merupakan aspek penting dalam pembentukan karakter anak. Perhatian yang besar dari orang tua dan reaksi timbal balik antara ibu dan anaknya. Menurut pakar pendidikan anak, seorang ibunya yang sangat perhatian pada anaknya yang berusia di bawah enam bulan (yang diukur dari seringnya ibu melihat mata anaknya, mengelus, menggendong dan berbicara pada anaknya) akan mempengaruhi sikap bayinya sehingga menjadi anak yang gembira, antusias mengksplorasi lingkungan dan menjadikannya anak yang kreatif (Direktorat Dikmas, 2011).

\section{Strategi Komunikasi dalam Mengasuh dan Mendidik Anak}

Keterlibatan orangtua/keluarga terhadap pengasuhan anak yang komprehensif dijelaskan oleh Apstein (2001) dalam Patmonodewo, bahwa ada 6 (enam) tipe keterlibatan dalam pengasuhan dan pendidikan anak, yaitu melibatkan unsur(1) pengasuhan, (2) komunikasi, (3) sukarela, (4) belajar di rumah, (5) pengambilan keputusan, dan (6) bekerjasama dengan masyarakat. Dalam hal komunikasi maka tujuannya adalah merancang bentuk yang efektif komunikasi antarkeluarga dengan tempat dimana anak mengikuti kegiatan pendidikan /pengasuhan.

Terdapat Paterns of Communicative Control (PCC) atau pola kontrol komunikasi yang merupakan suatu cara tersendiri dalam beraksi terhadap sesuatu yang ia terima dari komunikator lainnya (Miller \&
Steinberg, 1975). Pola kontrol komunikasi ini dapat digunakan sebagai strategi untuk pencapaian keinginan. Terdapat lima pola dalam kontrol komunikasi yaitu: (1) dangling carrot atau teknik pemberian imbalan yang bertujuan untuk mengubah tingkatan atau arah perilaku seseorang; (2) hanging sword atau strategi menghukum; (3) catalyst technique, yaitu suatu teknik di mana sumber menyarankan penerima untuk bekerjasama yaitu bersikap dalam suatu cara tertentu demi kepentingannya sendiri. Strategi ini digunakan agar individu berkelakuan dalam rangka memperkuat diri (self reinforcing) tanpa langsung memberi hadiah atau menghukumnya; (4) siamese twin strategy, yaitu suatu strategi yang dapat dijalankan pada dua orang yang memang sudah memiliki hubungan dekat dan saling memiliki ketergantungan dan memiliki kekuasaan yang sama dengan cara saling menghargai atau bahkan salah satunya dapat mengambil keuntungan dari yang lain karena menyadari bahwa keterikatan hubungan itu sangat tinggi; dan (5) fairyland strategy, yaitu cenderung mengabaikan respon yang tidak diinginkan dengan memberinya suatu arti positif, dengan kata lain strategi ini menghasilkan suatu kontrol ilusi daripada kontrol yang nyata.

Ada perbedaan antara mengajar dan mendidik. Mengajar itu menyangkut proses penyampaian ilmu pengetahuan, sedangkan mendidik menyangkut proses pembentukan manusia secara keseluruhan (Drost, 1998). Mengajar menjadi tugas sekolah sedangkan mendidik menjadi kewajiban orantu tua dan masyarkat di dalam komunitas. Menurut Drost bahwa pembentukan watak anak merupakan bagian pendidikan yang tidak boleh diserahkan orangtua kepada instansi lain. Seharusnya pemeran utama di dalam pendidikan adalah orangtua.

Kecenderungan orang tua saat ini sibuk mengurusi pekerjaan sehingga pendidikan untuk anak diserahkan kepada asisten rumah tangga. Sekolah menjadi tempat satu-satunya untuk mendidik anak sehingga sekolah merasa berat bila diserahkan untuk mendidik anak sepenuhnya. Peran mendidik seharusnya dipegang oleh orangtua, baru kemudian pendidikan di sekolah menegaskan, memperkuat dan meluruskan pendidikan yang sudah terbentuk di rumah.

\section{Pembentukan Karakter}

Karakter bukan sekedar hasil dari sebuah tindakan, melainkan secara simultan merupakan 
hasil dari proses. Dengan demikian pendidikan karakter merupakan keseluruhan dinamika rasional antar pribadi dengan berbagai macam dimensi, baik dari dalam maupun dari luar dirinya, agar pribadi itu semakin dapat menghayati kebebasannya, sehingga ia dapat semakin bertanggungjawab atas pertumbuhan dirinya sendiri sebagai pribadi dan perkembangan. Tujuan pendidikan yang mengarah pada pembentukan karakter adalah kebebasan dan otentisitas individu agar menjadi pribadi yang mampu mengembangkan tanggung jawab moral integral dalam membangun harmoni kehidupan bersama serta berbangsa dan bernegara.

Terdapat enam jenis karakter yang dapat dibentuk, yaitu: (1) trustworthiness, bentuk karakter yang membuat seseorang menjadi: berintegritas, jujur dan loyal; (2) fairness, bentuk karakter yang membuat seseorang memiliki pemikiran terbuka serta tidak suka memanfaatkan orang lain; (3) caring, bentuk karakter yang membuat seseorang memiliki sikap peduli dan perhatian terhadap orang lain maupun kondisi lingkungan sekitas; (4) respect, bentuk karakter yang membuat seseorang selalu menghargai dan menghormati orang lain; (5) citizenship, bentuk karakter yang membuat seseorang memiliki sikap peduli dan perhatian terhadap orang lain maupun kondisi sosial lingkungan sekitar; serta (6) responsibility, bentuk karakter yang membuat seseorang bertanggungjawab, disiplin, dan selalu melakukan sesuatu dengan sebaik mungkin (Chrisiana, 2005).

Berdasarkan hasil penelitian Heni (2011), karakter tidak dapat tumbuh sendiri tanpa pembinaan dan mentor yang berperan mengarahkan serta memberi contoh yang baik dan karakter tidak datang dengan sendirinya melainkan melalui proses, dibentuk dan ditumbuhkembangkan.

Karakter yang terbentuk dari bawaan karena latar belakang budaya sang anak dibentuk dari keluarga dan masyarakat, maka harusnya masyarakat diberi kesempatan untuk memiliki pendidikan apa yang dibutuhkan, bukan pendidikan nasional yang di homogenkan. Jadi, anak bisa berkembang sesuai dengan karakter akar budayanya. Pendidikan yang bersifat universal dapat dibuat seragam dalam pendidikan namun budaya adi luhur yang bersifat kearifan lokal sudah selayaknya untuk dipelihara, misalnya kebersamaan dalam keluarga, rasa malu bila melanggar norma yang berlaku, takut jika berbuat salah dan mencintai keluarga besar.

Orang tua dengan latar belakang budaya yang sudah mengakar dari kecil akan mengajarkan nilainilai budaya yang luhur yang didapatkan dari ayah ibunya kepada anak-anaknya. Begitu terus-menerus nilai-nilai adi luhur diturunkan secara turun-temurun.

Setiap komunitas pada dasarnya menjalankan pendidikan dalam rangka keberlangsungan komunitas tersebut. Pendidikan komunitas bertujuan mengembangkan tata cara dan karakter komunitas tersebut (Aant, 2015). Pendidikan komunitas yang cikal bakalnya ada dalam keluarga, tidak harus berupa institusi yang formal, justru peran utamanya ada pada keluarga. Usia yang paling cepat menangkap dan meniru semua sikap dan perilaku serta nilai-nilai keluhuran ditanamkan sejak anak ada dalam kandungan sampai usia masih dini.

Karakter anak dapat terbentuk dari pasangan ayah dan ibu yang berkarakter pula. Pendidikan mulai dari ayah dan ibu menikah sudah siap menjadi orang tua yang kelak memiliki anak yang diasuh sesuai dengan akar budaya ayah ibunya.

Seperti halnya yang disampaikan oleh Idris bahwa ada beberapa cara yang dilakukan oleh keluarga dalam membangun karakter anak antara lain membangun kejujuran, penanaman nilai-nilai agama, keikhlasan beribadah, beraktivitas, peduli sesama, dan kebersamaan. Selain memperkuat pendidikan dalam keluarga, Kementerian Pendidikan dan Kebudayaan dapat melakukan kerjasama dengan media televisi untuk mengurangi siaran yang dapat memperlemah moral, kejujuran atau toleransi antar sesama (2014).

Karakter dapat ditumbuhkan sejak anak usia dini. Penanaman dan penumbuhan karakter paling efektif melalui proses komunikasi dan teladan dari orangtua kepada anaknya.

\section{PENUTUP}

Penyampaian pesan dengan cara berkomunikasi antara orangtua dan anak usia dini penting dilakukan untuk membentuk karakternya setelah dewasa. Cara bicara, menyampaikan informasi, mencari tahu apa yang diinginkan anak, mencari tahu apa yang dirasakan anak perlu dilakukan dengan berkomunikasi agar ditemukan formula yan cocok untuk tindakan selanjutnya. Berkomunikasi juga memerlukan strategi untuk mencapai apa yang kita inginkan. Jika selama ini orangtua berkomunikasi, 
dengan cara tidak sengaja juga menanamkan karakter melalui komunikasi tersebut.

Setelah tahu bahwa komunikasi antarpribadi merupakan proses dalam menanamkan karakter kepada anak usia dini, maka segala bentuk komunikasi orangtua dan anak perlu direncanakan agar sesuai dengan yang diharapkan dalam mencapai tujuan membentuk karakter anak. Komunikasi antarpribadi tidak hanya dilakukan dengan kata-kata untuk menanamkan kejujuran, nilai moral dan agama tetapi juga dalam bentuk perilaku atau teladan serta tindakan yang menunjukkan kasih sayang kepada anak seperti mengelus, menggendong dan menepuk untuk memberikan motivasi kepada anak. Karakter yang terbentuk dari bawaan karena latar belakang budaya sang anak dibentuk dari keluarga. Jadi, anak bisa berkembang sesuai dengan karakter akar budayanya. Pendidikan yang bersifat universal dapat dibuat seragam dalam pendidikan namun budaya adi luhur yang bersifat kearifan lokal sudah selayaknya untuk dipelihara, misalnya kebersamaan dalam keluarga, rasa malu bila melanggar norma yang berlaku, takut jika berbuat salah dan mencintai keluarga besar.

\section{DAFTAR PUSTAKA}

Subhansyah, A. (2015). Komunitas bawa cara, sekolah bawa tata, antropologi pendidikan. Yogyakarta: Universitas Gadjah Mada, Jurusan Antropologi Budaya, Fakultas IImu Budaya

Seefeld, C., \& Barbour, N. (1986). Early childhood education: An introduction. Merril Publishing company: Toronto.

Chrisiana, W. (2005). Upaya penerapan pendidikan karakter bagi mahasiswa (studi kasus di jurusan teknik industri uk petra). Jurnal Teknik Indurstri Vol.7, No.1, Juni 2005: 83-90

Handayani, M. (2005). Interaksi komunikasi keluarga orang tua tunggal dalam konteks komunikasi antarpribadi (Studi kasus orang tua tunggal ibu yang memiliki anak usia dini di DKI Jakarta). Tesis. Fakultas IImu Sosial dan IImu Politik Jurusan IImu Komunikasi, Program Pascasarjana, Universitas Indonesia. Tidak diterbitkan

Waluyo, H. (2011). Pendidikan karakter: Apa, dan bagaimana implementasinya di satuan pendidikan. Jurnal Penelitian dan Evaluasi Pendidikan. Volume 4 tahun ke-2. April. Halaman 501.

Hornby, G. (2011). Parental involvment in childhood education, spreanger and he. Christchurch: University of Canterbury.

Noor, I.H.M. (2014). Reduksi nilai moral, budaya dan agama terhadap implementasi pendidikan karakter di sekolah. Volume 9 No.2 Desember 2014. Halaman 154.

Jourard, S.M. (1959). Self-disclosure and orther cathexis. Journal of Abnormal and Social Psychology.

Megawangi, R. (2003). Pendidikan karakter untuk membangun masyarakat madani. Depok: IPPK Indonesia Heritage Foundation.

Miller, G.R.,\& Steinberg, M. (1975). Between people a new analysis of interpersonal communication. Chicago: Science Research Associater.

Patmonodewo, M. (2010). Pengembangan pendidikan anak usia dini jalur informal melalui pendidikan keluarga. Jurnal IImiah Anak Usia Dini Vol.9, No.2, Juni.

Monk., F.J., Knoers, A.M.P.,\& Haditono, S.R. (1994). Psikologi perkembangan: Pengantar dalam berbagai bagiannya. Yogyakarta: Gadjah Mada Press.

O'Hair, Friederich, Wieman.,\& Wieman (1997). Competent communication. New York: St. Martin's Press Inc. 